\title{
ATL-like overgrowth and clonal expansion of HTLV-1 infected CD25+ CD4+ T- lymphocyte in humanized-NOG mouse model
}

\author{
Jun-ichi Fujisawa*, Kenta Tezuka, Runze Xun, Mami Tei, Norihiro Takenouchi, Masakazu Tanaka \\ From 15th International Conference on Human Retroviruses: HTLV and Related Viruses \\ Leuven and Gembloux, Belgium. 5-8 June 2011
}

Humanized mice (huNOG) established by the intrabone marrow transplantation of NOG-SCID mouse with CD133+ hematopoietic stem cells purified from human cord blood were infected with HTLV-1 in vivo by peritonial injection of $\gamma$-ray-irradiated MT-2 cells in 3 to 4 months after transplantation.

While normal differentiation of human $\mathrm{T}$ lymphocytes was observed in the spleen of uninfected huNOG mouse, HTLV-1 infection increased the number of CD25+ CD4+ T- lymphocytes and resulted in the splenomegaly within several months. In the late period of infection, where almost all of the blood cells in the mouse were composed of infected human T-lymphocytes, cells with highly lobulated or flower-shaped nuclei appeared in the peripheral blood.

Inverse PCR analysis of provirus integration sites revealed the polyclonal infection in the early phase and the oligoclonal expansion of infected $\mathrm{T}$ cells mostly in the population of CD25+CD4+ T- cells in the late phase. Since substantial amount of anti-Gag antibodies and Tax-specific CTLs were detected in the serum and the spleen of infected mice, respectively, the involvement of immune system against HTLV-1 was suggested in the clonal selection of HTLV-1 infected T-cells in this system.

Thus, the HTLV-1 infected huNOG mouse model should provide a valuable system for the analysis of ATL pathogenesis and the development of treatments against various HTLV-1 associated diseases. Results from the analysis of gene expression in HTLV-1 infected $\mathrm{T}$-cells during the course of infection and the effects of

\footnotetext{
* Correspondence: fujisawa@takii.kmu.ac.jp

Dept. Microbiology, Kansai Medical University, Moriguchi, Osaka, 570-8506, Japan
}

in vivo administration of various anti-tumor or anti-viral drugs on the overgrowth of infected T-cells will be discussed.

Published: 6 June 2011

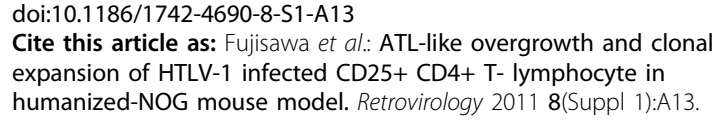

Cite this article as: Fujisawa et al:: ATL-like overgrowth and clonal expansion of HTLV-1 infected CD25+ CD4+ T- lymphocyte in humanized-NOG mouse model. Retrovirology 2011 8(Suppl 1):A13.

Submit your next manuscript to BioMed Central and take full advantage of:

- Convenient online submission

- Thorough peer review

- No space constraints or color figure charges

- Immediate publication on acceptance

- Inclusion in PubMed, CAS, Scopus and Google Scholar

- Research which is freely available for redistribution

Submit your manuscript at www.biomedcentral.com/submit
() Biomed Central

\section{Biomed Central}

